\title{
Genetical and Physiological Studies on a Thermosensitive Mutant of Escherichia coli Defective in Cell Division
}

\author{
By I. B. HOLLAND AND VALERIE DARBY \\ Department of Genetics, University of Leicester, Leicester LEI ${ }_{7} R H$
}

(Received 9 June 1975; revised 20 August 1975)

\begin{abstract}
SUMMARY
A new temperature-sensitive mutant of $E$. coli, defective in cell division, was isolated after selection for tolerance to colicin E2. The mutant strain, ASHI 24, growing in either minimal or complex medium, commences filament formation immediately upon shift to high temperature. High densities of bacteria or the presence of $0.44 \mathrm{M}$-sucrose prevents filament formation at $42{ }^{\circ} \mathrm{C}$ and division continues. Filament formation in the mutant is reversible and upon return to $29^{\circ} \mathrm{C}$ the multinucleate filaments divide up into normal-sized bacteria by a series of rapid but sequential divisions. In the presence of chloramphenicol at $29^{\circ} \mathrm{C}$, $25 \%$ of these division sites are still expressed. A genetic locus designated $\mathrm{fts} H$, apparently controlling both temperature sensitivity and filament formation, was provisionally mapped at minute 80 on the $E$. coli KI 2 map.
\end{abstract}

\section{INTRODUCTION}

The triggering of division in Escherichia coli is apparently determined by a complex series of events including the completion of chromosomal replication and the sequential synthesis of specific proteins during the cell cycle (see, for example, Donachie, Jones \& Teather, 1973; Slater \& Schaechter, 1974). In an attempt to analyse the regulatory basis of this process genetically, Ricard \& Hirota (1973) have identified seven genes in thermosensitive mutants of $E$. coli, which affect cell septation in some way. Several other reports of similar mutants have appeared in recent years (Reeve, Groves \& Clark, 1970; Nagai \& Tamura, 1972; Castellazzi, George \& Buttin, 1972; Zusman, Inouye \& Pardee, 1972; Stone, 1973), attesting to the complexity of the division process. Unfortunately, little useful information concerning the regulation of cell division has so far emerged from these studies. In embarking on the examination of yet another mutant, defective in cell division, we therefore set ourselves certain specific objectives: (i) the establishment of the uniqueness of this particular mutation by a detailed genetic analysis of its properties, including its location on the $E$. coli map; (ii) the determination, as far as possible, of the stage in the cell cycle which is primarily affected; (iii) the specific examination of the synthesis of many individual membrane proteins at both permissive and non-permissive temperatures with the improved techniques now available, in anticipation that this might lead to some understanding of the molecular basis of the mutational block. Finally, we introduced an element of selection into the isolation of the mutant by selecting initially for tolerance to an agent, colicin E2, acting on the cell surface, which blocks cell division in sensitive bacteria (see Holland, 1975). We present here the general properties of the mutant, including the mapping of the mutant locus $f t s H$ at minute 80 on the $E$. coli $\mathrm{KI} 2$ map. 


\section{METHODS}

Strains. Strain ASHI24, thyA metB str-r ftsH was isolated from strain ASHI (Buxton \& Holland, 1973) after 2-amino purine mutagenesis, as tolerant to colicin $\mathrm{E}_{2}$ at $30^{\circ} \mathrm{C}$ and unable to grow on nutrient broth plates at $42^{\circ} \mathrm{C}$. Subsequent tests confirmed that ASHI 24 formed multinucleate filaments in liquid medium after shift to $42{ }^{\circ} \mathrm{C}$. Strain ASHI 24I was obtained as a spontaneous, faster-growing derivative of ASHI 24 which still formed filaments at $42{ }^{\circ} \mathrm{C}$ but was no longer tolerant to colicin E2 or E3. Stocks of both strains were preserved as frozen $\left(-20^{\circ} \mathrm{C}\right)$ cultures in nutrient broth (Oxoid No. 2) containing $20 \%$ (w/v) glycerol.

Strain ASHI is an Hfr strain which displays both a clockwise and an anti-clockwise mode of conjugational transfer, originating near minute II on the chromosome (Buxton \& Holland, 1973).

Strain EDI002 ( $\mathrm{F}_{\mathrm{ts}} \mathrm{lac}^{+}$, transposition $\mathrm{Hfr}$, pro str-s) was obtained from P. Meacock (Broda, Meacock \& Achtman, 1972). A derivative of this strain mutant at the bfe locus (Buxton, 1971), and therefore resistant to E-colicins and bacteriophage BF23, was isolated for use in this study as described previously (Hill \& Holland, 1967); BWI I4 (Hfr P4X, uvrA thi str-s) and Hfr KLI6 (recA) were from Dr B. M. Wilkins.

Mutants ASH5 (an $\mathrm{F}^{-}$strain, coll ${ }^{\mathrm{R}}$ thr leu thi try his argHBCE lacY gal malT xyl mtl str-r tsx-r $\lambda^{-}$non ${ }^{+}$sup $E^{+}$) and $\mathrm{Hfr}_{4}$ (bfe thr leu thiA $\phi 80^{\mathrm{B}}$ ) are Leicester laboratory strains (see also Threlfall \& Holland, I970; Taylor \& Trotter, 1967).

Strain ASH503 $\left(\mathrm{F}^{-}\right.$col $\mathrm{I}^{\mathrm{B}}$ thr leu try lac $Y$ gal malT str-r $\lambda-u v r A$ cycA fts $\left.H\right)$ was obtained from a cross between Hfr BWII4 and ASH5OI ( $\mathrm{F}^{-}$ftsH cycA arg $H$ str-r) and selecting for $\arg H^{+}$[str-r].

Media and cultural conditions. Minimal medium (M9), supplemented with amino acids where necessary, nutrient broth (NB), and conditions for growth of aerated cultures were all as described (Buxton \& Holland, 1973).

Preparation of colicins. Colicins $\mathrm{E}_{3}$ and $\mathrm{E}_{2}$ were prepared from $E$. coli $\mathrm{CA} 38$ (colicin $\mathrm{E}_{3}{ }^{+}$) and Salmonella typhimurium LT2, 906 (colicin E2-P9) respectively and assayed as described (Hill \& Holland, 1967). Colicin I was prepared from E. coli strain BWI3I (colicin Ibdrd) kindly provided by Dr B. M. Wilkins.

Coulter counting. Total cell numbers in bacterial cultures were determined with a Coulter counter, model B, as described (Holland \& Holland, 1970).

Microscopy. Examination of bacteria was carried out using a Wild phase-contrast microscope (Wild Heerbrugg Ltd, Heerbrugg, Switzerland). Bacteria were stained with polyvinylpyrrolidone as described by Stone (1973), to detect nuclear bodies. For counting bacteria and filaments, bacterial samples were mixed with $0.5 \%$ formalin, concentrated ro-fold to about $2 \times 10^{8}$ bacteria $/ \mathrm{ml}$, mixed with NB containing $0.4 \%(w / v)$ agar, and this mixture was allowed to solidify on a Thoma haemocytometer cell.

Measurement of macromolecular synthesis. Incorporation of $\left[{ }^{3} \mathrm{H}\right]$ uracil $\left[{ }^{14} \mathrm{C}\right]$ thymine, and

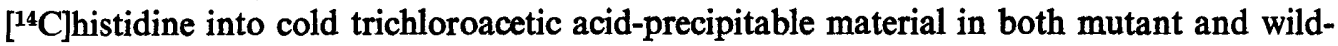
type strains at $42^{\circ} \mathrm{C}$ was carried' out as described (Holland, 1968; Senior, Kwasniak \& Holland, 1970). Cultures were pre-labelled at $29^{\circ} \mathrm{C}$ with the appropriate isotope for one to two generations as indicated in the text, before temperature shift. For the measurement of phospholipid synthesis, $\left[{ }^{3} \mathrm{H}\right]$ glycerol incorporation into trichloroacetic acid-precipitable material was determined in wild-type and mutant strains at either 29 or $42{ }^{\circ} \mathrm{C}$. Final specific activity of $\left[{ }^{3} \mathrm{H}\right]$ glycerol was $0.2 \mu \mathrm{Ci} / \mu \mathrm{g}$. Previous studies (Daniels, I969; Dr P. Beard, personal communication) have indicated that 80 to $100 \%$ of $\left[2(n)-{ }^{3} \mathrm{H}\right] \mathrm{glycerol}$ is incorporated into the phospholipid fractions of growing bacteria. 
Isotopes. $\mathrm{L}-\left[\mathrm{U}-{ }^{14} \mathrm{C}\right]$ histidine $(500 \mathrm{mCi} / \mathrm{mmol}),\left[5,6-{ }^{3} \mathrm{H}\right] \mathrm{uracil}(40000 \mathrm{mCi} / \mathrm{mmol}),\left[2-{ }^{14} \mathrm{C}\right]-$ thymine $(60 \mathrm{mCi} / \mathrm{mmol})$ and $\left[2(n)-{ }^{3} \mathrm{H}\right] \mathrm{glycerol}(100$ to $500 \mathrm{mCi} / \mathrm{mmol})$ were all obtained from the Radiochemical Centre, Amersham, Buckinghamshire.

Conjugational analysis. Crosses were usually carried out at $30^{\circ} \mathrm{C}$ and recombinants purified by two cycles of re-streaking on selective plates before testing. All other procedures, including methods of analysis of 3 and 4 factor crosses, have been described (Buxton \& Holland, 1973).

Phenotype tests. Suspensions of recombinants in buffer were cross-streaked against bacteriophage $\mathrm{BF} 23$, or $\lambda$ on nutrient-agar, and incubated overnight at $30{ }^{\circ} \mathrm{C}$; colicin sensitivity tests were carried out similarly. Ultraviolet sensitivity was determined as before (Buxton \& Holland, 1974). In determining sensitivity to cycloserine, samples were spotted on to M9 minimal agar containing $2.5 \times 10^{-5} \mathrm{M}$ D-cycloserine and incubated for $36 \mathrm{~h}$ at $30{ }^{\circ} \mathrm{C}$. Temperature sensitivity was determined at $42{ }^{\circ} \mathrm{C}$ after spotting samples on nutrient agar and incubation for $16 \mathrm{~h}$.

Isolation of cycA mutants. An exponential-phase culture of strain ASH5O I grown in nutrient broth was concentrated and about $2 \times 10^{8}$ bacteria plated on M9 minimal agar containing $2.5 \times 10^{-5} \mathrm{M}$ D-cycloserine as described by Russell (1972). This selects for mutations at the $c y c A$ locus at minute 84 on the $E$. coli KI 2 chromosome (Taylor \& Trotter, 1972). Several spontaneous mutants were picked, purified and shown to grow in the presence of $2.5 \times 10^{-5} \mathrm{M}$-cycloserine but not at higher concentrations $\left(\mathrm{IO}^{-4} \mathrm{M}\right)$. One such mutant was kept and the presence of the $c y c A$ locus confirmed in subsequent genetic analysis.

\section{RESULTS}

\section{Inhibition of division in strain ASH 24}

When the fts $H$ mutant ASH 24 , growing exponentially at $29{ }^{\circ} \mathrm{C}$ in either M9-glucose medium or NB, was shifted to $42{ }^{\circ} \mathrm{C}$, multinucleate filaments which lacked detectable septa under the phase-contrast microscope were produced. The kinetics of this effect were determined by measurement of bacterial number in the Coulter counter and by the determination of $E_{450}$ in the same culture. Virtually complete inhibition of division occurred, apparently with little or no delay, upon temperature shift (Figs. I and 4 ). In minimal glucose medium, with ASHI 24 and some of its derivatives, incubation at $42{ }^{\circ} \mathrm{C}$ eventually resulted in clumping and consequently in an apparent loss in number of bacteria (Fig. $1 b, c)$. However, this effect occurred some time after the onset of filament formation and was not observed in cultures grown in nutrient broth.

Filament formation could be suppressed by raising the osmolarity of the growth medium (Fig. I c), as found with many Fts mutants (Reeve, Groves \& Clark, 1970; Ricard \& Hirota, 1973). Filament formation at $42{ }^{\circ} \mathrm{C}$ was also absent in cultures of high bacterial density ( $>3 \times 10^{7}$ to $4 \times 10^{7}$ bacteria $/ \mathrm{ml}$ ). This effect, which was not investigated further, was previously observed with a thermosensitive mutant by Stone (1973), who suggested that growth under conditions of limiting oxygen tension might be the factor causing suppression. The Fts mutant BUG6, studied by Reeve et al. (I970), is also reported to divide normally when shifted to $42{ }^{\circ} \mathrm{C}$ at high bacterial densities (J. N. Reeve, personal communication).

\section{Effect of temperature shift upon macromolecular synthesis}

Cultures of ASHI and ASHI24 in nutrient broth were grown for several generations at $29^{\circ} \mathrm{C}$ in the presence of $\left[{ }^{14} \mathrm{C}\right]$ thymine, before shifting to $42{ }^{\circ} \mathrm{C}$ in the presence of the isotope. Incorporation at $42{ }^{\circ} \mathrm{C}$ continued for at least $\mathrm{I} .5 \mathrm{~h}$, precisely in parallel with the increase 


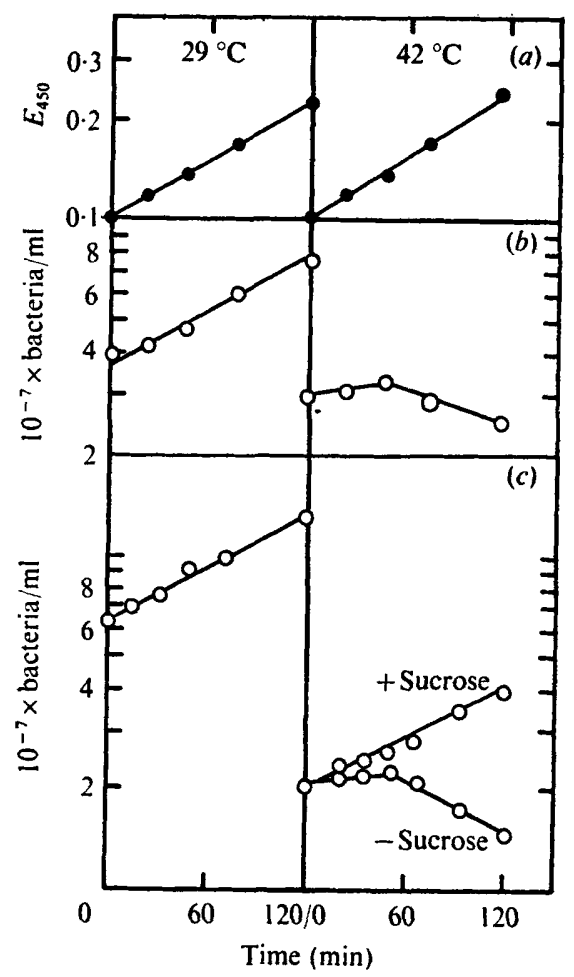

Fig. I

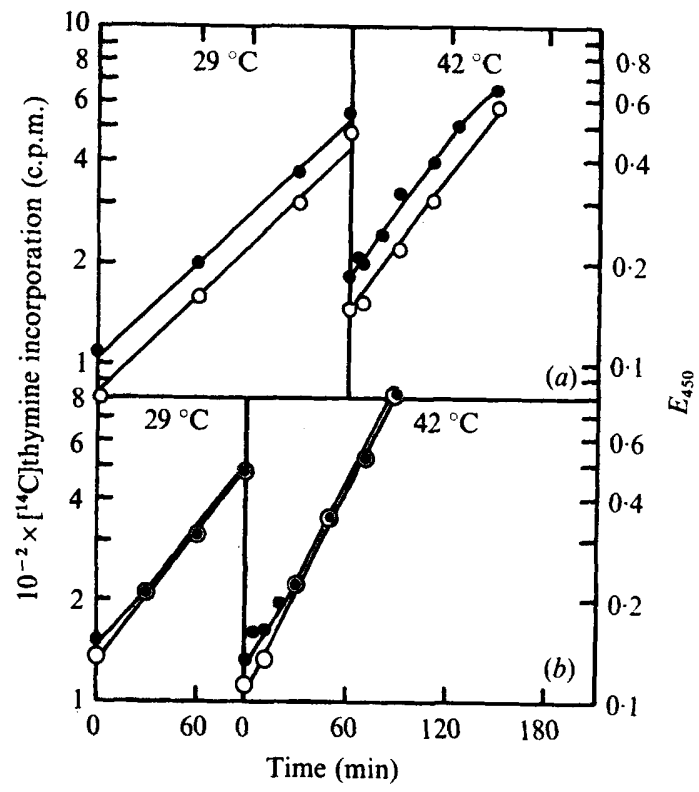

Fig. 2

Fig. I. Inhibition of division in ASHI $24\left(\mathrm{ftsH}^{-}\right)$after temperature shift. Strain ASH 24 growing in M9-glucose with shaking at $29^{\circ} \mathrm{C}$ was diluted in pre-warmed medium and incubation continued at $42^{\circ} \mathrm{C}$. Samples were removed at intervals and $(a)$ extinction measured at $450 \mathrm{~nm}$ or $(b)$ bacterial number determined in a Coulter counter. In (c), a similar culture of ASHI 24 was shifted to $42{ }^{\circ} \mathrm{C}$ in the presence or absence of $0.44 \mathrm{M}$-sucrose.

Fig. 2. Effect of temperature on DNA synthesis. Strain ASHI $24\left(f t s^{-}\right)(a)$ and parental strain ASHI (b) were grown with shaking in nutrient broth at $29^{\circ} \mathrm{C}$ with [ [14 C]thymine (final specific activity 0.06 $\mu \mathrm{Ci} / \mu \mathrm{g})$. After $90 \mathrm{~min}$, the cultures were diluted to approximately $2 \times 10^{7}$ bacteria $/ \mathrm{ml}$ in medium containing $\left[{ }^{14} \mathrm{C}\right]$ thymine of identical specific activity. Incubation at $29^{\circ} \mathrm{C}$ was continued and samples were removed at intervals to determine extinction or incorporation of [14 $\mathrm{C}$ thymine into acid-precipitable material. When the cultures reached a density of $0.5\left(\mathrm{E}_{450}\right)$, cultures were diluted 5 -fold into pre-warmed medium containing [ $\left.{ }^{14} \mathrm{C}\right]$ thymine and labelling was continued at $42{ }^{\circ} \mathrm{C}$.

, acid-precipitable [ $\left.{ }^{14} \mathrm{C}\right]$ thymine; $\mathrm{O}, \mathrm{E}_{450}$.

in $E_{450}$ (Fig. 2). DNA synthesis in the mutant therefore appears to continue normally at the restrictive temperature.

The effect of temperature shift upon RNA and protein synthesis was also examined (Fig. $3 a, b$ ). In both strains the rates of incorporation initially exceeded the increase of extinction, but after about $60 \mathrm{~min}$ the synthesis of RNA and protein in both mutant and wild-type strains was observed to continue to increase in parallel with total cell mass as measured by $E_{450}$. Phospholipid synthesis in the mutant was determined by following incorporation of $\left[{ }^{3} \mathrm{H}\right]$ glycerol into acid-precipitable material. Phospholipid synthesis in the mutant also continued after temperature shift, at a rate which precisely paralleled the rate of increase in extinction (Fig. 3c). From all these experiments it may be concluded that inhibition of cell division in the mutant cannot therefore be ascribed to any permanent imbalance in the synthesis of these major cell constituents at the restrictive temperature. 

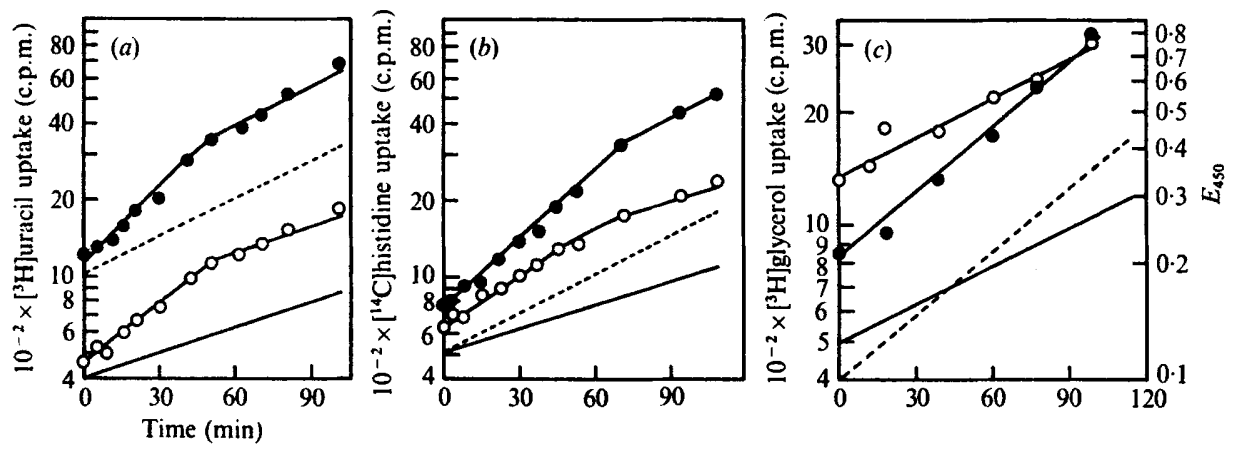

Fig. 3. Effect of temperature shift on protein, RNA and phospholipid synthesis. Strains (O) AsHr and (O) ASHI $24\left(\mathrm{fts}^{-}\right)$were grown at $29^{\circ} \mathrm{C}$ in'Mg-glucose medium containing radioactive isotope for $60 \mathrm{~min}$, or for $120 \mathrm{~min}$ for $\left[{ }^{3} \mathrm{H}\right] \mathrm{glycerol}$ labelling. At time zero, cultures were diluted 3 to 4 -fold into pre-warmed, fresh medium containing isotope and incubation was continued at $42{ }^{\circ} \mathrm{C}$; samples were removed at intervals and incorporation of radioactivity into acid precipitable material determined. - - - Mass increase $\left(E_{450}\right)$ for ASHI ; - mass increase in strain ASHI 24. Initial specificactivities in the medium: (a) [ $\left.{ }^{3} \mathrm{H}\right]$ uracil, $0.4 \mu \mathrm{Ci} / \mu \mathrm{g} ;\left(\right.$ b) $\left[{ }^{14} \mathrm{C}\right]$ histidine, $0.0013 \mu \mathrm{Ci} / \mu \mathrm{g} ;(c)\left[{ }^{3} \mathrm{H}\right] \mathrm{glycerol}, 0.2 \mu \mathrm{Ci} / \mu \mathrm{g}$.

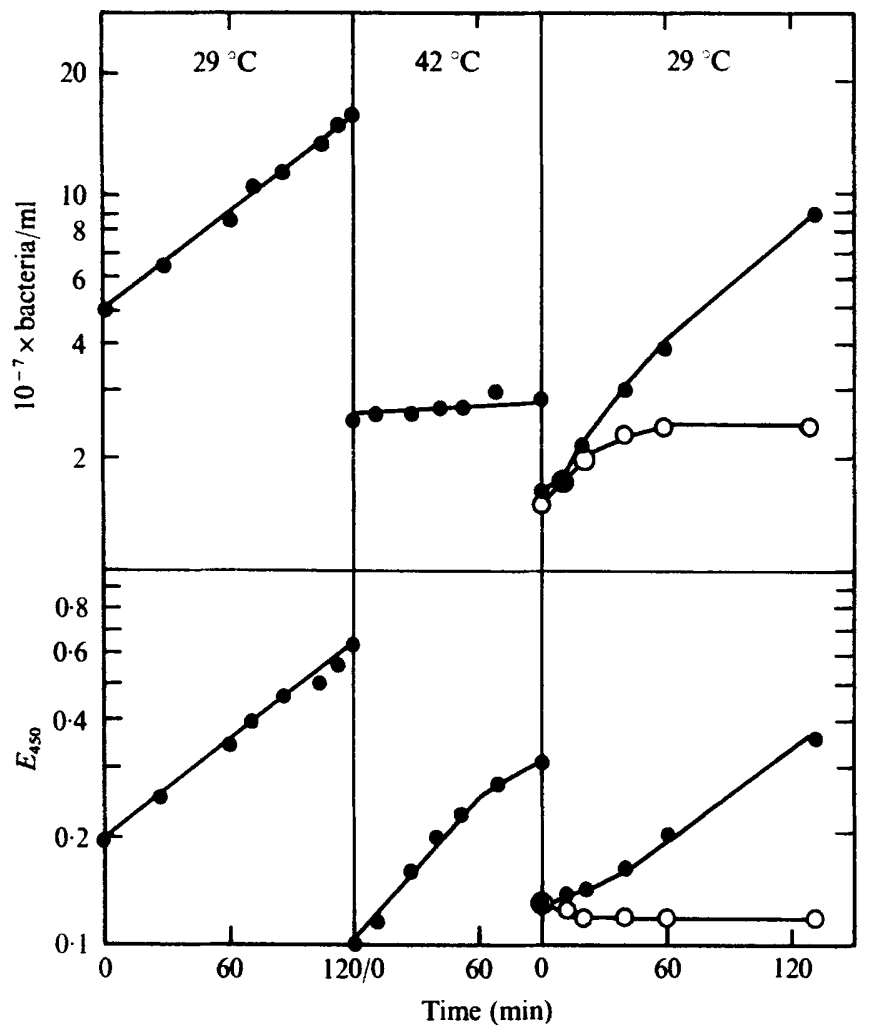

Fig. 4. Division of ASH 24 filaments upon return to $29^{\circ} \mathrm{C}$. Strain ASH 24 was first grown in nutrient broth at $29^{\circ} \mathrm{C}$, before dilution and shifting to $42{ }^{\circ} \mathrm{C}$ after $2 \mathrm{~h}$. Incubation was continued at $42^{\circ} \mathrm{C}$ for 75 min and filament formation confirmed by phase-contrast microscopy. Samples were removed at intervals throughout for determination of extinction and number of bacteria. Finally, the culture was again diluted and shifted back to $29^{\circ} \mathrm{C}$. Half the culture received $75 \mu \mathrm{g}$ chloramphenicol $/ \mathrm{ml}$ at this stage $(O)$; half did not $(0)$. 


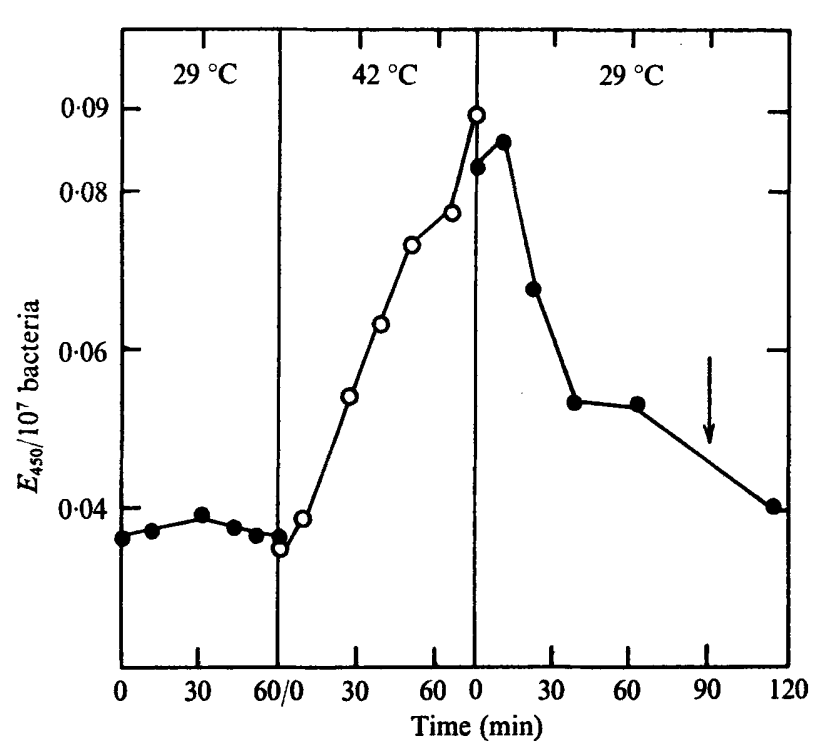

Fig. 5

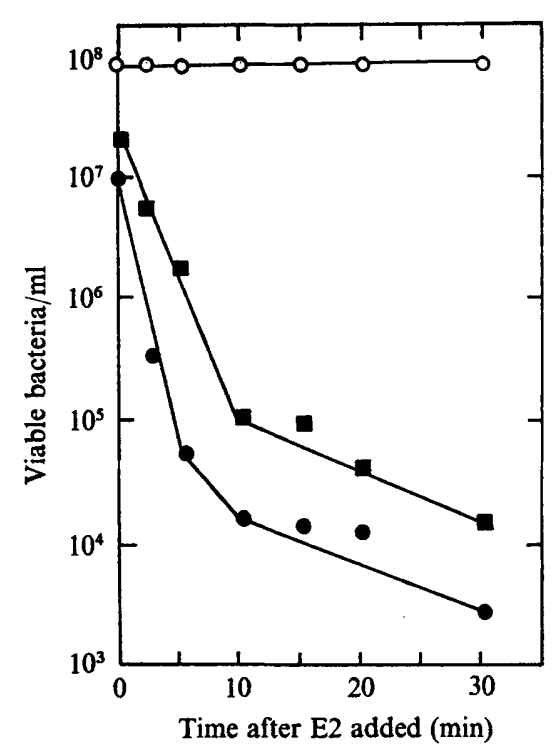

Fig. 6

Fig. 5. Effect of temperature shift on bacterial size in strain Ashr 24. With the data obtained from the experiment described in Fig. 4, extinction $/ 10^{7}$ bacteria was calculated and plotted against time at various temperatures. The arrow indicates the time when the extinction had doubled after return to $29^{\circ} \mathrm{C}$.

Fig. 6. Sensitivity of Fts mutants to colicin E2. Exponential cultures of ( $\square$ ) ASHI $\left(f t s^{+}\right)$, (O) ASHI 24 $(f t s H)$, and $(O)$ the faster-growing derivative ASHI $24 \mathrm{I}(\mathrm{ftsH})$, grown in nutrient broth at $30^{\circ} \mathrm{C}$, were diluted in broth to about $2.5 \times 10^{7}$ bacteria $/ \mathrm{ml}$ and treated with colicin E2 ( 5 units $/ 10^{7}$ bacteria) at $29^{\circ} \mathrm{C}$. Samples were removed at various times, diluted in buffer, plated in duplicate on nutrient broth agar and incubated overnight at $-30^{\circ} \mathrm{C}$ to determine the fraction of surviving bacteria.

\section{Expression of division potential in ASHI24 upon return to low temperature}

Strain ASHI 24 growing in NB medium was shifted to $42{ }^{\circ} \mathrm{C}$ for 70 min (about $\mathrm{I} \cdot 5$ doublings). By the end of this period the resultant filaments had attained a length two to three times that of normal rods. The culture was then diluted into fresh medium at $29^{\circ} \mathrm{C}$ and the kinetics of subsequent division determined (Fig. 4). The filaments began to divide almost immediately after the shift to low temperature. The rate of division, however, was now almost twice the rate of increase of $E_{450}$, and after $2 \mathrm{~h}$ virtually all bacteria were of normal size (Fig. 5). Thus, division potential acquired during incubation at $42{ }^{\circ} \mathrm{C}$ is rapidly expressed at low temperature. However, the rate of division observed on return to $29^{\circ} \mathrm{C}$ indicated that dividing up of the filaments was occurring sequentially rather than by abrupt fragmentation into bacteria of normal size. This was confirmed by phase-contrast microscopy, which revealed that filaments at $29^{\circ} \mathrm{C}$ which showed visible 'septa' (i.e. which were in the process of cell separation) almost invariably contained only a single septum. In a sample of I3I I bacteria examined under phase-contrast (Table IA) only two filaments were observed containing two septa. These results are consistent with a random distribution of the single septum between division sites, situated at polar, subpolar or central positions within the filaments. Thus although the formation of normal-sized bacteria is initiated in a successive fashion, the position of each cleavage plane appears to be distributed randomly amongst potential division sites.

The ability of filaments to divide was also examined in the presence of chloramphenicol. 
Table I. Analysis of septum position in ASHI 24 filaments upon return to $29^{\circ} \mathrm{C}$

\begin{tabular}{|c|c|c|c|c|c|c|}
\hline $\begin{array}{c}\text { Time } \\
\text { at } 29^{\circ} \mathrm{C} \\
(\mathrm{min})\end{array}$ & $\begin{array}{l}\text { No. of cells } \\
\text { counted }\end{array}$ & $\begin{array}{c}\text { Central } \\
(\%)\end{array}$ & $\begin{array}{c}\text { Terminal } \\
(\%)\end{array}$ & $\begin{array}{c}\text { Subterminal } \dagger \\
(\%)\end{array}$ & $\begin{array}{c}\text { Normal } \\
\text { rods } \\
(\%)\end{array}$ & $\begin{array}{c}\text { Total } \\
\text { septa } \\
(\%)\end{array}$ \\
\hline \multicolumn{7}{|c|}{ (A) Untreated culture } \\
\hline 0 & 335 & $1 \cdot 2$ & $1 \cdot 5$ & 0.35 & $6 \cdot 0$ & $3 \cdot 0$ \\
\hline 5 & 370 & $4 \cdot 3$ & $I \cdot 7$ & 2.95 & $8 \cdot 5$ & 8.9 \\
\hline 10 & 89 & 3.4 & $2 \cdot 2$ & $6 \cdot 7$ & $14 \cdot 6$ & $12 \cdot 3$ \\
\hline 15 & 100 & $8 \cdot 0$ & $8 \cdot 0$ & $8 \cdot 0$ & $25 \cdot 0$ & $24: 0$ \\
\hline 30 & 417 & $5 \cdot 9$ & $5 \cdot 9$ & $2 \cdot 2$ & $30 \cdot 0$ & $15 \cdot 0$ \\
\hline
\end{tabular}

(B) Culture treated with chloramphenicol $(75 \mu \mathrm{g} / \mathrm{ml})$ at $29^{\circ} \mathrm{C}$

$\begin{array}{rrrrr}91 & 2 \cdot 2 & 1 \cdot 1 & 0 & 7 \cdot 6 \\ 75 & 2 \cdot 7 & 2 \cdot 7 & 2 \cdot 7 & 12 \cdot 0 \\ 124 & 8 \cdot 1 & 4 \cdot 0 & 0 & 13 \cdot 7 \\ 142 & 2 \cdot 1 & 7 \cdot 0 & 1 \cdot 4 & 21 \cdot 0 \\ & \text { * One cell length from a pole. } \\ & \text { Teptum between central and terminal positions. }\end{array}$

Division of the filaments did continue in the presence of the drug but abruptly ceased when about one-quarter of all potential division sites had been utilized (Fig. 4). Analysis of the positioning of the septum under these conditions revealed no preference for central rather than polar cleavage sites (Table I B). However, there was some indication that subpolar localization of the septum may be rather less frequent in filaments exposed to chloramphenicol (Table I B).

\section{Other properties of strain ASHI 24 and one of its derivatives}

Mutant ASH 24 is a slow-growing strain with a mean generation time of $88 \mathrm{~min}$ at $29^{\circ} \mathrm{C}$ (in supplemented minimal glucose medium) compared with 55 min for the parent strain. In addition, growth yields from glucose grown cultures at $29^{\circ} \mathrm{C}$ were found to be only $80 \%$ of those obtained with the parent strain (data not shown) which may indicate some slight defect in energy metabolism in the mutant. In the course of this study a faster-growing derivative (mean generation time for supplemented minimal glucose of $73 \mathrm{~min}$ ) appeared spontaneously in stocks of the mutant. This strain, ASHI 24I, nevertheless still retained the Fts phenotype. Very slow growth rates and inability to divide at high temperatures are therefore separable properties in strain ASHI 24. Tolerance to colicin E2, the property originally used to select Fts mutants, was also separable from thermosensitivity since ASHI 24I was completely sensitive to colicin E2 (Fig. 6). Both ASHI 24 and ASHI 24I, however, gave very small indistinct plaques and reduced plating efficiencies $(<10 \%)$ with bacteriophage $\lambda$ compared with the parental strain at $30^{\circ} \mathrm{C}$.

\section{Genetic mapping of fts by conjugation analysis}

To facilitate the genetic analysis of the fts locus, strain ASHI24I was crossed with ASH5, a multi-auxotrophic $\mathrm{F}^{-}$strain; a $\left.\mathrm{xyl}^{+}{ }^{+} \mathrm{ColI}^{\mathrm{B}}\right]$ recombinant (strain $\mathrm{ASH}^{-} \mathrm{OI}$ ), which was also temperature sensitive, was obtained. The data resulting from this cross indicated that $f t s$ was located in the 70 to 90 minute region. Consequently a derivative of ASH50I, strain ASH503, was constructed (see Methods), carrying the markers $c y c A$ ( 84 minutes) and $u v r A$ (8I minutes). This strain was then crossed with $\mathrm{Hfr}$ EDIOO2 (bfe), whose origin of transfer is close to minute 63, and selection made for the late marker, thr leu (Table 2). In addition, ASH5OI was crossed with $\mathrm{Hfr} \mathrm{J}$, whose origin of transfer is at minute 8I, and selection made 


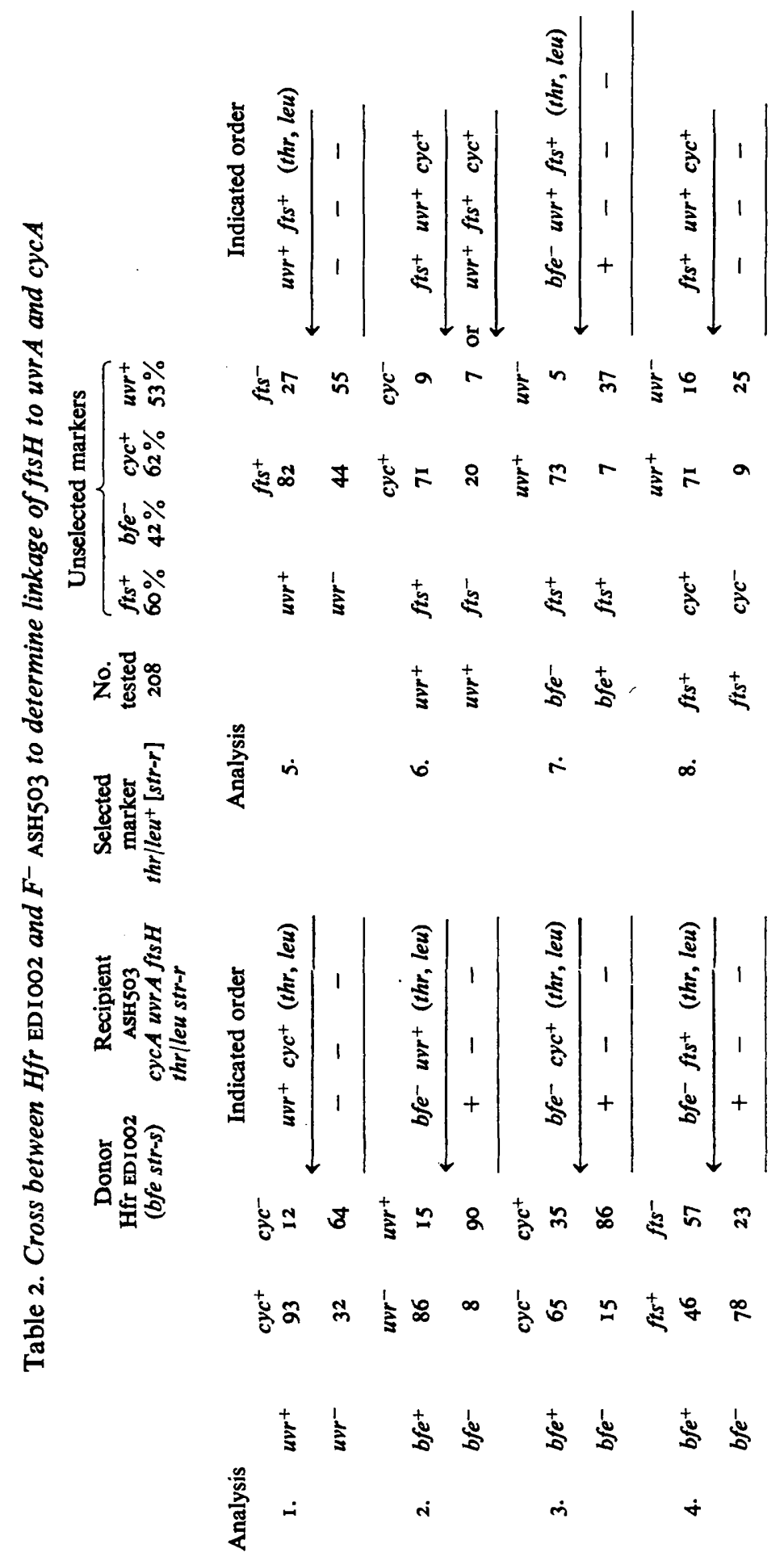


Table 3. Conjugational transfer of fts $\mathrm{H}$ by $\mathrm{Hfr} \mathrm{J} 4$

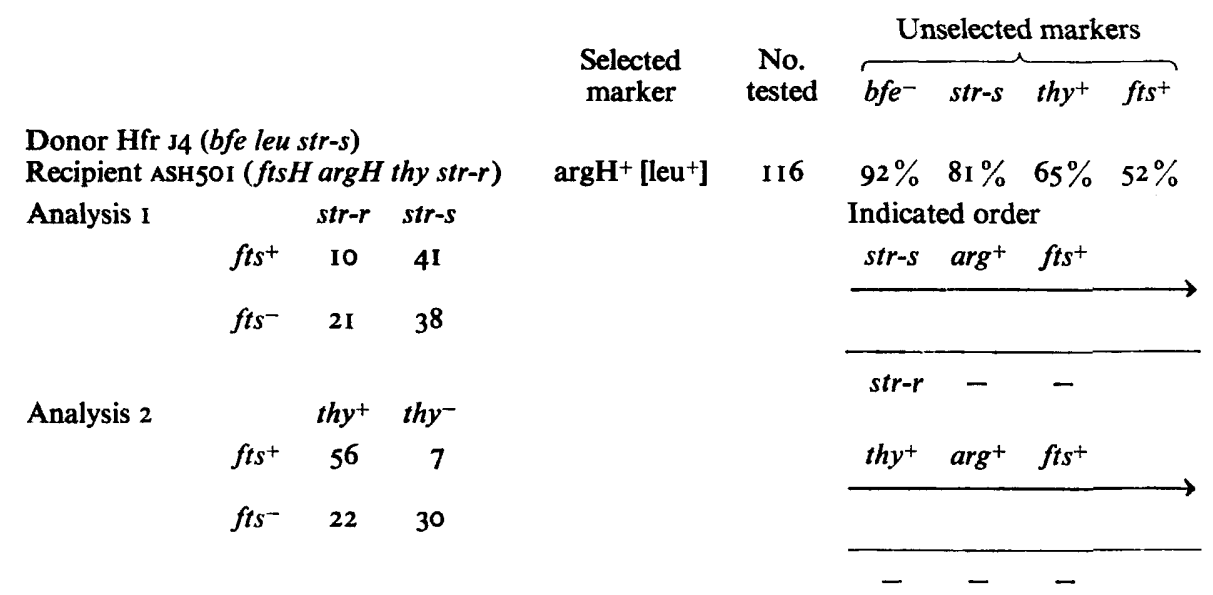

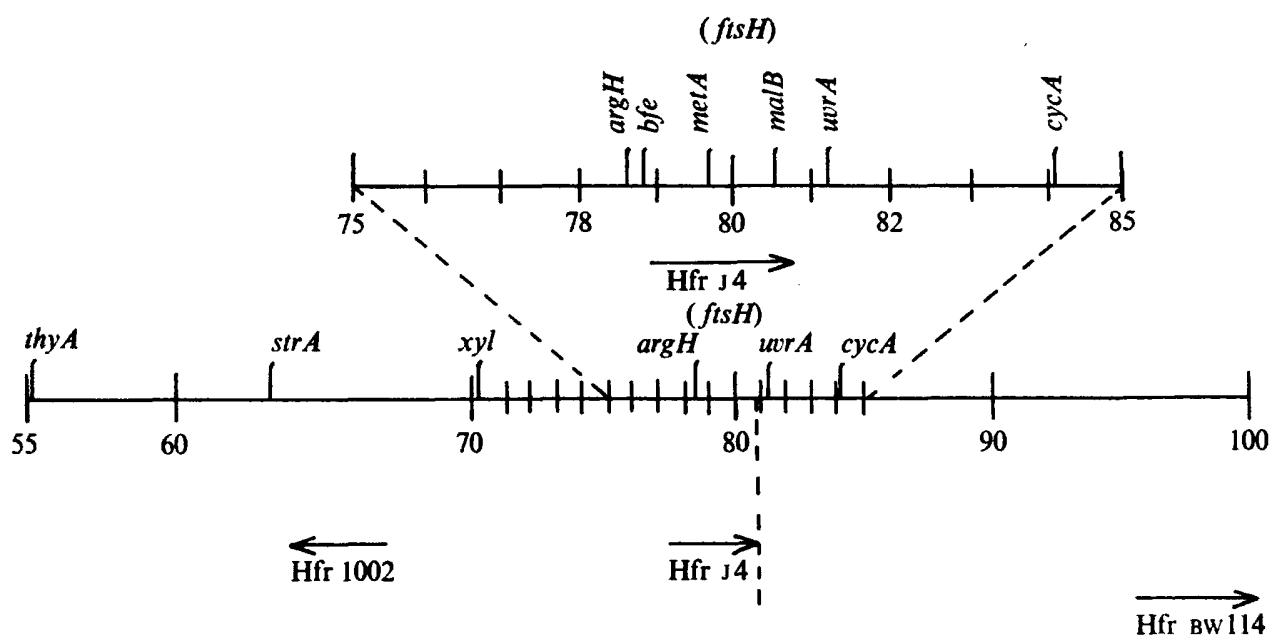

Fig. 7. Escherichia coli $\mathrm{K} 12$ map showing point of origin of Hfr strains (Taylor \& Trotter, 1967, 1972) used in this study and the approximate position of the fts $H$ locus.

for the early marker, $\operatorname{argH}$ (Table 3). In contrast to Hfr EDI002, Hfr J4 transferred in an anti-clockwise direction (see Fig. 7). The analysis of the unselected markers from these crosses demonstrated that $f t s$ was transferred at high frequency by both Hfr strains. This places $f t s$ between minutes 63 and $8 \mathrm{I}$, and therefore to the left of $u v r A$ which is transferred as a terminal marker by Hfr J4 (Taylor \& Trotter, 1967). Moreover, since Hfr J4 is $\lambda^{r}$, due to the integration of the $F^{-}$factor at the malB locus (B. Low, personal communication), $f t s$ is also to the left of malB. In addition, several lines of evidence indicated that $f t s$ is to the right of $\operatorname{argH}$ and $b f e$ at minute 79 . Thus from the cross with $\mathrm{Hfr}$ EDI002, fts was mapped to the right of bfe (Table 2, analysis 4) and the failure unambiguously to order fts and $u v r A$ in this cross (Table 2, analyses 5,6,7 and 8) indicated the closeness of these latter two markers. From the cross with Hfr $\mathrm{J}_{4}, \mathrm{fts}$ was mapped to the right of arg $H$ (Table 3, analyses $I$ and 2). Inspection of the data in Table 3 reveals that $f t s$, despite its presumed 
proximal position on the $\mathrm{Hfr} \mathrm{J} 4$ chromosome, is found less frequently amongst recombinants than the distal markers str and thy $A$. This, however, is to be expected if $f t s$ is very close to the origin of transfer of $\mathrm{Hfr} \mathrm{J} 4$ and consequently subject to early marker depression of recombinant formation. On the basis of all the conjugation data we therefore conclude that $f t s$ is close to minute 80 on the $E$. coli chromosome and that the probable map order is arg H-bfe-fts-malB as shown in Fig. 7.

\section{DISCUSSION}

The properties of the strains discussed here appear to fulfil the minimum requirements of putative division mutants (see review by Slater \& Schaechter, 1974). Moreover, the genetic locus apparently determining filament formation in these strains is distinct from the seven loci, $f t s A$ to $G$ previously mapped by Ricard \& Hirota (1973). In particular, $f t s D$ was reported by these workers to map at minute 78 but the fts locus investigated in this study mapped to the right of this region at minute 80 . In accordance with the nomenclature of Ricard \& Hirota we therefore designate this locus as $\mathrm{ftsH}$.

Division of ASHI 24 was blocked immediately upon shift to high temperature and resumed, with little or no lag, on return to low temperature, indicating a defect which is expressed very late in the cell cycle. This suggests that even cells late in the D-period (Pierucci \& Helmstetter, 1969) fail to carry out some essential step in septum formation, upon temperature shift. DNA replication and nuclear segregation did, however, continue but unlike env mutants (Normark, Boman \& Bloom, 1971) chain formation was never observed. As seen with other division mutants (e.g. Reeve \& Clark, 1972) $\mathrm{fts} H$ strains appear to accumulate division potential, i.e. to construct incomplete or inactive division sites during growth at $42{ }^{\circ} \mathrm{C}$. Completion of these sites is accomplished rapidly at a rate faster than further mass increase upon return to the permissive temperature, and the filaments divide up to produce bacteria of normal size. Nevertheless, such divisions are clearly sequential, indicating either some physical restraint upon simultaneous, multiple ingrowths of the cell envelope or the presence of limiting amounts of a cellular constituent, which serves a catalytic role in septum formation. Unfortunately, reports in the literature on similar studies are sufficiently unclear on this point for it to be impossible to assess whether this pattern of division is the norm after division delay, or a feature unique to $\mathrm{fts} H$ mutants. Whatever is the basis of sequential division, under these conditions, septum formation is successively triggered, apparently at random, from any one of several possible sites, within each filament.

On the basis of the limited physiological studies so far carried out with strain ASHr24, any speculation upon the nature of the temperature-sensitive component, or its possible role in the normal division process is unwarranted at this stage. Since some studies have indicated (unpublished data) that $\mathrm{fts} H$ mutants have altered envelopes, future studies will examine the synthesis of membrane proteins in the mutants under a variety of conditions. In particular, these studies will seek to establish whether any membrane changes are primary or secondary effects of mutational changes at the $\mathrm{ftsH}$ locus, and whether this necessarily indicates the specific involvement of the $f t s H$ gene product in division. 


\section{REFERENCES}

Broda, P., Meacock, P. \& Achtman, M. (1972). Early transfer of genes determining transfer functions by some Hfr strains in Escherichia coli. Molecular and General Genetics 116, 336-347.

BuxTon, R. S. (1971). Genetic analysis of Escherichia coli K1 2 mutants resistant to bacteriophage BF23 and the E-group colicins. Molecular and General Genetics II3, I 54-I 56.

Buxton, R. S. \& Holland, I. B. (1973). Genetic studies of tolerance to colicin E2 in Escherichia coli K-I 2. I. Re-location and dominance relationship of cet mutations. Molecular and General Genetics 127, 69-88.

Buxton, R. S. \& Holland, I. B. (1974). Genetics studies of tolerance to colicin E2 in Escherichia coli K-I 2. II. Multiple mutations as a cause of the various phenotypic properties of $\mathrm{Cet}^{-}$mutants. Molecular and General Genetics 131, I 59-171.

Castellazzi, M. J., George, J. \& Butrin, G. (1972). Prophage induction and cell division in Escherichia coli. Molecular and General Genetics II9, I53-174.

DANIELS, M. J. (1969). Lipid synthesis in relation to the cell cycle of Bacillus megaterium KM and Escherichia coli. Biochemical Journal 115, 697-701.

Donachie, W. D., Jones, N. C. \& Teather, R. (1973). The bacterial cell cycle. Symposia of the Society for General Microbiology 23, 9-44.

HIIL, C. \& Holland, I. B. (I967). The genetic basis of colicin E sensitivity in Escherichia coli K-I2. I. Isolation and properties of refractory mutants and the preliminary mapping of their mutations. Journal of Bacteriology 94, 677-686.

Holland, E. M. \& Holland, I. B. (1970). Induction of DNA breakdown and inhibition of cell division by colicin E2. Nature of some early steps in the process and properties of the E2-specific nuclease system. Journal of General Microbiology 64, 223-239.

Holland, I. B. (1968). Properties of Escherichia coli $\mathrm{k} 12$ mutants which show conditional refractivity to colicin E2. Journal of Molecular Biology 31, 267-275.

Holland, I. B. (1975). Physiology of colicin action. Advances in Microbial Physiology 12, 56-1 39.

NAGAI, K. \& TAMURA, G. (1972). Mutant of Escherichia coli with a thermosensitive protein in the process of cellular division. Journal of Bacteriology I12, 959-966.

Normark, S., Boman, H. G. \& BloOM, G. D. (197I). Cell division in a chain-forming envA mutant of Escherichia K12. Acta pathologica et microbiologica scandinavica B 79, 65I-664.

PierucCi, O. \& Helmstetter, C. E. (1969). Chromosome replication, protein synthesis and cell division in Escherichia coli. Federation Proceedings 28, $1755-1760$.

ReEve, J. N. \& Clark, D. J. (1972). Cell division of Escherichia coli BUG-6. Effect of varying the length of growth at the non-permissive temperature. Journal of Bacteriology Iro, I I 7-I 21 .

Rreve, J. N., Groves, N. G. \& Clark, D. J. (1970). Regulation of cell division in Escherichia coli: characterization of temperature-sensitive division mutants. Journal of Bacteriology 104, 1052-1064:

RICARD, M. \& HIROTA, Y. (1973). Process of cellular division in Escherichia coli: physiological study on thermosensitive mutants defective in cell division. Journal of Bacteriology 116, 314-322.

RusselL, R. R. B. (1972). Mapping of a D-cycloserine resistance locus in Escherichia coli K-I 2. Journal of Bacteriology III, 622-624.

Senior, B. W., Kwasniak, J. \& Holland, I. B. (1970). Colicin E3-directed changes in ribosome function and polyribosome metabolism in Escherichia coli K12. Journal of Molecular Biology 53, 205-220.

Slater, M. \& Schaechter, M. (1974). Control of cell division in bacteria. Bacteriological Reviews $3^{8}$, I99-22I.

STONE, A. B. (1973). Regulation of cell division in a temperature sensitive division mutant of Escherichia coli. Journal of Bacteriology 116, 741-750.

TAYLOR, A. L. \& TROTTER, C. D. (1967). Revised linkage map of Escherichia coli. Bacteriological Reviews 31, 332-353.

TAYLOR, A. L. \& TROTteR, C. D. (1972). Linkage map of Escherichia coli strain K-r 2. Bacteriological Reviews 36, 504-524.

Threlfall, E. J. \& Holland, I. B. (1970). Co-transduction with serB of a pleiotropic mutation affecting colicin E2 refractivity, ultraviolet sensitivity, recombination proficiency and surface properties of Escherichia coli K1 2. Journal of General Microbiology 62, 383-398.

Zusman, D. R., INouYe, M. \& PARdee, A. B. (1972). Cell division in Escherichia coli: evidence for regulation of septation by effector molecules. Journal of Molecular Biology 69, I19-138. 